\title{
CONVEX FUNCTIONS AND MEANS OF MATRICES
}

\author{
MOHAMMAD SABABHEH
}

Abstract. In this article, we prove that convex functions and log-convex functions obey certain general refinements that lead to several refinements and reverses of well known inequalities for matrices, including Young's inequality, Heinz inequality, the arithmetic-harmonic and the geometric-harmonic mean inequalities.

Mathematics subject classification (2010): 15A39, 15A60, 15B48, 26A51, 47A30, 47A60, 47A63.

Keywords and phrases: Convex functions, Heinz means, means inequalities, unitarily invariant norm inequalities, Young's inequality.

\section{REFERENCES}

[1] M. Bakherad, M. Moslehian, Reverses and variations of the Heinz inequality, Linear Multilinear Algebra 63, 10 (2015), 1972-1980.

[2] M. BAKHERAD, M. KRniĆ, AND M. Moslehian, Reverses of the Young inequality for matrices and operators, Rocky Mountain Journal of Mathematics, to appear.

[3] T. Furuta, J. Mićić Hot And J. PeČArić, Mond-Pečarić Method in Operator Inequalities, Element, Zagreb, 2005.

[4] E. HeInZ, Beitrage zur Storungstheoric der Spektralzerlegung, Math. Ann. 123 (1951), 415-438.

[5] O. HirZallah and F. KitTAneh, Matrix Young inequalities for the Hilbert-Schmidt norm, Linear Algebra Appl. 308 (2000), 77-84.

[6] F. Kittaneh And Y. ManasRah, Improved Young and Heinz inequalities for matrices, J. Math. Anal. Appl. 36 (2010), 262-269.

[7] W. LIAO AND J. Wu, Reverse arithmetic-harmonic mean and mixed mean operator inequalities, J. Inequal. Appl., 2015: 215.

[8] M. SABABheH AND D. Choi, A complete refinement of Young's inequality, J. Math. Anal. Appl. 440, (1) (2016), 379-393, DOI: 10.1016/j.jmaa.2016.03.049.

[9] M. SABABHeh, Log and Harmonically log-convex functions related to matrix norms, Operators and Matrices 10, 2 (2016), 313-325.

[10] M. S AвАBнEH, Interpolated inequalities for unitarily invariant norms, Linear Algebra Appl. 475 (2015), 240-250. doi:10.1016/j.laa.2015.02.026.

[11] H. XING-KAI, Young type inequalities for matrices, Journal of east China normal university (Natural Science) 4, 4 (2012), 12-17.

[12] J. ZHAO AND J. Wu, Operator inequalities involving improved Young and its reverse inequalities, J. Math. Anal. Appl. 421 (2015), 1779-1789.

[13] H. Zuo, G. SHI AND M. FujII, Refined Young inequality with Kantorovich constant, J. Math. Inequal. 5, 4 (2011), 551-556. 